\title{
Wasatiyyah and Islamic Values in Reinforcing Malay Muslim Ethnic Relations: A Case Study of Thai Wasatiyyah Institute for Peace and Development in Thailand
}

\author{
Sulaiman Dorloh ${ }^{1 *}$ \\ Kamarussalam Bin Yusuf² \\ ${ }^{1}$ Faculty of Shari'ah \& Law, UNISSA, Brunei Darussalam. \\ ${ }^{2}$ Faculty of Business\& Management Sciences, UNISSA, Brunei Darussalam. \\ *Coresponding Author, Email: dsulaiman@unissa.edu.bn
}

\begin{abstract}
:
The Wasatiyyah or moderation Institute for Peace and Development was initiated by the current Chularajmontri, Aziz Pithakkompon on 21th August 2014, with the aims of fostering harmony among the diverse ethnics in the country and providing a counter-balance to extremism and extremist as it is taking place in various parts of the world and promoting moderation and peace among Muslims in Thai society. The concept of wasatiyyah or moderation is appropriate to be highlighted and practiced in Thai society to curb extremist activities in all matters. Even though some negative perceptions were voiced by a few parties, but the actual intentions could result in a decline of racial strains, as being moderate has been the practice of the Malay community and its leaders for ages. In fact, this approach has contributed to the success of the Malay community in the Deep South in securing the Malay indentity from their Buddhist neighburs in the country, without having to resort to spilling a lot of blood. Based on previous research, it was observed that the concept of wasatiyyah had a great influence on the Malays, as it had a strong link with the Islamic values that have been embedded in the Malay community. The Islamic values are the main elements that shape the Malays' conduct, and it is the results of interaction with social norms, for it has bred certain social values that include compromise, modesty, respect and cooperation as transpired when Malays interact among themselves or with other communities. The main goal for the institution to maintain peace and harmony in the society. Based on textual analysis, the study determines that the concept of wasatiyyah concept or moderation is part of the social values borne out of the Malays' values based on Islamic teachings. Hence, the question is, to what extent does the wasatiyyah concept implemented in the institute. In order to answer the question above, this study has set two main objectives. First, to identify the wasatiyyah concept in Islamic law; and second, to analyse its implementation in the institude. The qualitative study in the form of exploratory and descriptive approach used the content analysis method. The content analysis method was used to identify and analyse the wasatiyyah concept in Islamic law and also to analyse the implementation of the wasatiyyah concept in the institute.
\end{abstract}

Keywords: Concept, Wasatiyyah, Thailand, Chularajmontri.

\section{A. INTRODUCTION}

Extremism (al-Guluw) is not something new but rather it has emerged at every important juncture in world history. After the cold war, new counties had emerged that brought along extremism based 
on right wing racism. These racial antagonisms had caused conflicts and ethnic killings of a magnitude not witnessed since World War Two (WWII) in 1945, especially in Bosnia Herzegovina and Rwanda (Mohd Azizuddin Mohd Sani, 2013; Hanapi, 2014).

In the West, this concept is called 'moderation'. It was introduced by Aristotle since the time of the Greeks. Zainal Kling further explains that, "The phrase, moderation in all thing is common extrapolation of Aristotle's Doctrine of the Mean (as presented in his Nicomachean Ethics). His ethic works around finding the mean, or middle ground, between excess and deficiency. An example of this would be his presentation of courage being the happy medium between the extreme of rash action and deficiency of cowardice, in respect to a person's possible action in the face of danger". The Christians had also accepted the moderation concept. This was indirectly quoted by Paul when referring about a good sportsman "And everyone who competes for prize is temperate in all things. Now they do it to obtain a perishable crown, but we for an imperishable crown". Moderate is the opposite of being a fundamentalist-extremist, which portrays a very 'lose' religious attitude. Hence, according to the perspective of a moderate, if one holds a strong religious attitude such as being obedient to all the religious commandments, then one is a fundamentalist. This thinking actually emerged from the Christians from the West who were uncomfortable with the Evangelicals who basically held firm to the Bible and they were also called fundamentalist (Ghazali Basri, 2008:124; Hanapi, 2014:52).

Overall, the discussions in this paper are divided into three main parts. First, the discussion focuses on the wasitayyah (wasațiyya) concept that has been highlighted in al-Qur'an and Hadith; second, the discussion on the implementation of the wasatiyyah concept in Thai society with a specific focus on Wasatiyyah Institute for Peace and Development in Thailand and third, to discuss the pararellism of the wasatiyyah concept in al-Qur'an and hadith with the wasatiyyah ascribed in the Wasatiyyah Institute for Peace and Development.

\section{B. METHODS}

This research used textual analysis that determines the concept of wasatiyyah concept or moderation is part of the social values. The question is, to what extent does the wasatiyyah concept implemented in the institute.

\section{RESULT AND DISCUSSIONS}

\section{Terminological discussion}

There have been a number of terminologies associated with wasatiyyah, as in the English literature, such as moderation, mainstream, intermediacy, middle path, midpoint, reasonable, rational, acceptable, common, and others. There were however, a number of terms, which did convey certain paradoxes to wasatiyyah as it's presently known in the Islamic literature. One such example was the concept of al-Așabiya or al-Taaașsub (excessive love of one's tribe), which was very common during the pre-Islamic era and later, was developed to what lbn Khaldun (d. 1406) defined as a "group feeling". Other Arabic terms, which have certain contradictions to wasatiyyah are al-lghāl (beyond exaggeration), al-Tashaddud (exceedingly restrictive), al-Guluw (excessiveness, extremism), al-Tațarruf (moving to the farthest point and going the extra mile), while some scholars such as al-Qaradawi even includes alTașawwuf (mystical experience). (IIUM-IIW; 2014). 


\section{Thai Wasatiyyah Institute for Peace and Development (WIPD)}

In light of the above, the Wasatiyyah Institute for Peace and Development (WIPD) was established, at the Sheikh Islam Office in Bangkok, on August 21, 2014. It is a non-partisan institute, which aims at fostering and enhancing moderation among members of the Muslim Ummah, through a variety of intellectual activities such as research and studies, trainings, workshops, forums, seminars, conferences, publications, and dialogue. The Thai government headed by Thai Muslim spiritual leader Aziz Phitakkumpon, the Chularatchamontri or Sheikhul Islam of Thailand, at the Sheikhul Islam Office in Bangkok had introduced the wasatiyyah approach to implement the Wasatiyyah concept. According to Isara Santisart (excerpt from), Deputy Chairman for policy committee at the Wasatiyyah Institute for Peace and Development, was of of view that the institute was set up aiming at providing a counter-balance to Islamic extremism as it is taking place in various parts of the world and promoting moderation and peace among Muslims in Thai society.

\section{The Concept of Wasatiyyah}

The term "al-Wasatiyyah" is derived from the word wasat (wasaț). Actually, this term was taken and elaborated from the word ummatan wasațan (the moderate people), which is found in the Holy Qur'an, Allah SWT says:

"Thus, have We made of you an Ummat justly balanced, that ye might be witnesses over the nations, and the Messenger a witness over yourselves; and We appointed the Qibla to which thou were used, only to test those who followed the Messenger from those who would turn on their heels (from the Faith). Indeed, it was (a change) momentous, except to those guided by Allah. And never would Allah Make your faith of no effect. For Allah is to all people most surely full of kindness, Most Merciful." (al-Baqarah, 2:143).

In this verse, Allah SWT explains that the Islamic people are ummatan wasațan. There are numerous interpretations by the religious scholars (mufassirin) regarding the term wasatan, which is found in verse 143 in Surah al-Baqarah. According to Ibn Kathir (1992:196-197) wasațan means the best, humblest and being fair, whereas Al-Qurtubi (1993:104-105), wasațan means fair and the best. In this context, it does not mean taking a central or middle position in a matter, such as a position between good and bad. The term "wasațan" also carries the meaning of 'average', and is also referred to as 'fair, 'the best, 'the respected and 'the chosen'. For wasatiyyah also means khayriyyah, that is, making the best choice - a meaning, which derives from the Qur'an and also the Arabic usage of the word (Kamali, 2014).

According to Nik Salida Shuhaila (2012), the stance of observing average and moderation are the Malay community's way of life when interacting, whether among themselves or with other non-Malay communities. The concept was further cultivated in the soul of the Malays when Islam arrived in the Malay realm around the $7^{\text {th }}$ A.D. As a result, the Malays resorted to enhancing the concepts in performing their daily activities, such as when interacting with others in order to heed to the teachings of Islam (Nik Salida Shuhaila, 2012; Husin, 2013:529). There are several aspects of Muslim culture and behavior in the Malay-Indonesian communities, which reflect Islamic moderation, but they have not been getting the attention of the Western media in their desire to prop up the scripted narrative of Muslim extremism and militancy. Relatively speaking, they are among the most tolerant and accommodative Muslim communities in the world, despite the Western media's tendency to sensationalize or exaggerate news about the incidents of Muslim violence or militant attacks. (Hassan, 2013). 


\section{The Relationship between Wasatiyyah and Islamic Values}

According to Muhammad Hanif bin Hassan (2014) ${ }^{1}$, M. Kamal Hassan has explained the concept of moderation by using a graphic representation (see Figure 1), which is profound, yet clear to understand, unlike the usually heavy and convoluted academic works on the subject. Below is graphic presentation of the concept and structure of Wasatiyyah.

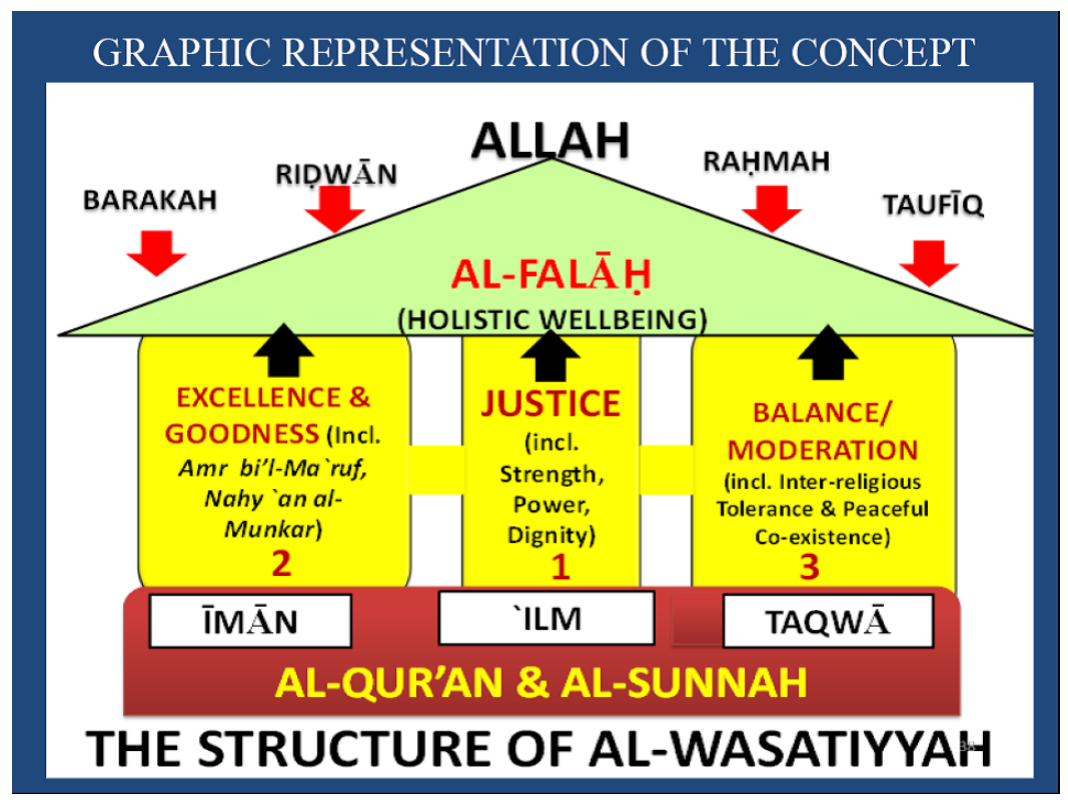

Figure 1: the concept of moderation (Hassan, 2014)

First and foremost, according to Prof. M. Kamal Hassan, moderation as an Islamic concept must be grounded on Islam's two primary sources; the Quran and the Sunnah (the Prophet's tradition). Based on these two primary sources, Prof. Hassan premised the concept of wasatiyyah on three key Islamic values 1) immān (belief), 2) 'ilm (knowledge) and 3) taqwā (compliance to divine guidance). Prof. Hassan does not elaborate much on these three values. However, it could be safely deduced that, by imann, he refers to primarily belief in Allah as the only God (monotheism) and Muhammad is His final Messenger. This a standard belief held by every Muslim and there is no reason to believe that Prof. Hassan is different in this regard.

Muhammad Hanif (2014) was of the view that the reason why Prof Hassan positions knowledge as the foundation for wasatiyyah. The importance of knowledge in Islam and, thus, its position as one of the key foundations for such an important concept in Islam - wasatiyyah - can be easily deduced from the fact that it was mentioned together with the issue of belief in Allah in the first revelation to Muhammad (see 96:1-5). Furthermore, knowledge presupposes everything in Islam. One can never believe in the true God without knowledge; what more to uphold the concept of wasatiyyah.

As of taqwā, its importance and centrality in Islam is also an undisputed issue among scholars. Thus, it is understandable if there isn't elaboration from Prof Hassan too. What is more important, from Prof. Hassan's illustration, is his conception that wasatiyyah is not the only concept from which everything in Islam is built upon, despite its importance and centrality and this has important implications. Firstly; To be moderate or to practice wasatiyyah is important but it must not be at the 
expense of the more important pillars of Islam, secondly; a Muslim's understanding and practice of religion must be shaped by the right understanding of wasatiyyah but that understanding itself is not free from any intellectual and conceptual bindings and thirdly; Wasatiyyah or moderation cannot be pursued at all costs or interpreted without binding parameters. Based on this, it should be deduced that the meaning of the word wasatiyyah itself must be based primarily on what these two sources say about moderation and being moderate and not just by mere philosophical thinking or the perceptions of Muslim laymen.

Zainal Kling (2012: 17) the Head of Heritage History and Socio-cultural Cluster of the National Professors' Council of Malaysia stated that wasatiyyah values in together will unite the hearts, feelings and thoughts of the people in the pursuit of progress and development in the efforts to safeguard the interests of fellow citizens and distributing the wealth fairly so that all levels of society will feel the well-being, safety and happiness together. In proving the matter, JAKIM (2011: 5) has outlined seven aspects of the wasatiyyah implementation desired by the government, such as wasatiyyah in religious life, education, legal, social and cultural development, economics, government governance and the context of international relations.

In conclusion, Professor Dr. M Kamal Hassan also emphasized the need for balance, goodness and justice as the three in-separable elements for a moderate society. Wasatiyyah concept should not be interpreted as a way of life that brings Muslims backward, left behind in all their life in the world or hereafter. Wasatiyyah concept is more geared to create a Muslim community with attitudes, actions and practices which are not extreme or radical and inclined to extreme limits in each state, forgetting moral values and spiritual and beyond the boundary of civilization values for the rights and fulfill its obligations at the expense of innocent lives, clashes between religious and others.

\section{Wasatiyyah, Extrimist and Religious Tolerence}

The indication that religious tolerance has declined in Southern Thailand, something that might have a negative impact on interfaith relations (ASEP;14:3). These are due to the long bitter history of injustice or oppression by the central government, or aggressive Christian evangelization in Muslim dominant areas, or the infiltration by external militant elements that do not represent the wishes and aspirations of the masses or the elites. (Hassan, 2013) To assist the Muslim leaders and organizations in countering the militant or extremist tendencies among the youth or religious groups, we believe it is useful for them to consider undertaking what al-Qaraḍ̄̄wīhas described as the seven necessary changes (Just to mention a few) that Islamic movements and activists should undergo. (Al-Qaraḍāwīi, al-Ṣaḥwah al-Islāmiyyah, 10-52; M. Kamal Hassan). They are as follows:

\section{Changing from Form and Outer Appearance to Reality and Substance.}

The substance of Islam is not about "growing the beard and lengthening it; shortening of the robe; carrying the miswā $k$ (teeth-cleaning stick); joining one's foot with other's foot in prayer; placing the hands on the chest or above the navel; eating while seated not while standing; forbidding all kinds of songs or music; making the wearing of the niqā $b$ (face cover) obligatory for women, etc." The substance of Islam as an 'aqīdah is tawhìd, that of 'ibāda is sincerity, that of mu'āmala (transaction) is truthfulness, that of khuluq (character) is mercy, that of tashrī' (legislation) is justice, that of 'amal (work) is perfection, that of adāb (ethics) is spiritual consciousness, that of 'alāqah (human bonds) is brotherhood, and that of civilization is balance. 


\section{From sentimental ('âţifiyyah) and clamourous behaviour (ghawghāiyyah) to rational and scientific attitude.}

It is true that being sentimental or emotional is a common trait of being human, but this trait should not be allowed to dominate over the intellect or reason. Allah (S.W.T) demands His servants and vicegerents always to be just in dealing with fellow creatures and not to be influenced by the destructive emotion of base desires: "O you who believe! Stand out firmly for justice as witnesses to Allah, even as against yourselves, or your parents, or your kin, and whether it be (against) the rich or the poor, for Allah can best protect both. Follow not the lusts (of your hearts), lest you swerve, and if you distort (justice) or decline to do justice, verily Allah is well acquainted with all that you do". (Q. Al-Nisā' 4: 135)

The Prophet SAW afforded the freedom of religion to those who were not from the Islamic faith. This matter was in line with the exhortations of Allah SWT:

"Let there be no compulsion in religion: Truth stands out clear from Error: whoever rejects evil and believes in Allah hath grasped the most trustworthy hand-hold, that never breaks. And Allah heareth and knoweth all things." (al-Baqarah, 2:256).

The 2007 of Thai Constitution specifies the state shall "patronize and protect Buddhism as the religion observed by most Thais for a long period of time and other religions, and shall also promote a good understanding and harmony among the followers of all religions as well as encourage the application of religious principles to create virtue and develop the quality of life." This law explains the freedom accorded to other religions, besides Buddhism to practice their religion. Hence, followers of other religions cannot ridicule or belittle the Islamic faith or Islamic religion, including other religions according to their fancy. Section 30 of the 2007 constitution states that unjust discrimination against a person on the grounds of differences in "religious belief" shall not be permitted.

\section{Proposed Wasatiyyah Lesson Module}

What are the required lesson modules? It is certainly a big question, but the author may define some aspects of common serious work in order to seek and create an atmosphere of mutual understanding and trust confidence building through open dialogue and permanent deliberations in order to facilitate reaching policies that will serve the interests of the government and society at large particularly, Muslims in Thailand. Within such policies must be: 1) To work effectively and actively to settle the Patanians question based on legal international resolutions and reference. 2) To help in solving the crises and conflicts suffered by the Muslims in the south with necessary objectivity, which make the solutions to be elements for permanent peace, security and stability. 3) To cooperate and assist in the socio-economic development of the Deep south provinces in order to strengthen the democratic structure on the country. 4) To study the reasons for frustration, which creates an environment favorable to terrorism, and to confront the terrorist actions with preventive and curative policies and precautions, which need not necessarily be purely military. 5) To make plans for executing awareness campaigns in order to remove all intellectual misconceptions from the other party's thoughts. 6) To make plans for the spread of objective media coverage.

\section{CONCLUSION}

Indeed, the continuous efforts by the office of Chularajmontri introducing (Thai) Wasatiyyah Institute for Peace and Development (TWIPD) in promoting moderation, balance and justice as the essences 
of wasatiyyah approach to all levels of community in order to establish peace and harmony in the country. The development of a harmonious Thai society is a long journey process that requires support and commitment from all levels of community regardless of their belief, culture and social status. It is worth to mention that a society that practices wasatiyyah in their thinking and actions will have a high level of tolerance and acceptance. The differences between them will no longer be the reason for disunity and disharmony. Therefore, It is suggested that Wasatiyyah lesson module for training must be dynamic and reflect the three Islamic values- imān, ilm and taqwā as proposed by Prof M.K Hassan, the Institute should focus on the implementation of the concept Wasatiyyah as a whole, for the sake of Islamic prestige and the well-being of the people as a dream state is a state which is good and forgiven by Allah (baldat tayyibah wa rabb ghafür). It is hoped that this article and my humble observations will be useful in building a wasatiyyah-minded generation that put the importance of development of a harmonious community as one of our priority. In case of Thailand land wasatiyyah approach is very important to fostering harmony among the diverse ethnics in the country and providing a counter-balance to extremism and extremist as it is taking place in various parts of the world by promoting moderation and peace among Muslims in Thai society. 


\section{References}

Hanapi, Mohd Shukri. (2014). The wasatiyyah (moderation) concept in Islamic epistemology: a case study of its implementation in Malaysia. International Journal of Humanities and Social Science, 4 (9), 1

Hassan, M. Kamal. (2013). The Concept of Al-Wasatiyyah and the Significance of Islamic moderation, IIUM. In International Conference on Terrorist Rehabilitation \&Community Resilience, on 26-27 March 2013. Singapore: Nanyang Technological University.

Husin, Wan Norhasniah Wan. (2013). International Journal of Social Science and Humanity. 3 (6).

Kamali, Mohammad Hashim. (2014). Islam, Globalisation and Wasatiyyah. International Institute of Advanced Islamic Studies (IAIS) Malaysia.

International Religious Freedom Report for 2011 United States Department of State, Bureau of Democracy, Human Rights and Labor

Yousif, Ahmad F. (2015), Applications of Wasatiyyah in the Contemporary Muslim World", IIUM Press. 